\title{
Bíró Annamária
}

\section{Aranka Ember Esmérete. Egy kéziratos filozófiai értekezés}

A kolozsvári Egyetemi Könyvtár Aranka-gyüjteményében található egy szerzői autográfia, $A z$ Ember Esmérete címmel. E tanulmány célja a kézirat elolvasása, az eredeti változat és más, hasonló címmel ellátott kéziratok rövid egybevetése, a szöveg eszme- és múfajtörténeti interpretációja.

A kéziratot tartalma teszi érdekessé, amely a felvilágosodás és reformkor határán az ember definíciójára, filozófiai, pszichológiai, társadalmi szempontú megközelítésére törekszik. Aranka filozófiájáról eddig nagyon kevesen írtak, kritikusai esetleg megemlítik, hogy ilyen témájú írásai is vannak, ${ }^{250}$ de jóakaratü elhallgatással a jövő kutatóira hagyják ezeknek a feltárását. Érdekes azonban megvizsgálnunk, hogyan jut el a tudományszervezö és költö, Aranka György, idösebb korára egy mindenki számára érthető filozófia megfogalmazásához, hogy a társadalmi és kulturális életben bekövetkezett csalódások után hogyan és miért menekül a bölcselkedés magányába.

Jancsó is megemlíti, ${ }^{251}$ hogy 1795 és 1815 között alig volt az erdélyi magyar életnek olyan kérdése, amely Aranka képzeletét ne foglalkoztatta volna. Ö volt az elsö, aki Shakespeare-t magyarra fordítja, ugyancsak ő hirdette először Erdélyben a néprajzi és honismereti kutatások fontosságát. Érdekelték a népi babonák, elfelejtett kéziratok és kallódó történeti emlékek, a mezögazdaság fejlesztése és elvont természettudományi problémák, nem utolsósorban a nyelveredet és a nyelvújítás. Jancsó Elemér nem tér ki bỏvebben Aranka bölcseletre irányuló érdeklődésére.

A környezete részéröl érkező csendes gúny s sokszor hangos megvetés ellenére Aranka nem mond le szándékáról, a fiatal erdélyi tudományszervezỏk útjából félreállva, a kor filozófusait és bölcselkedőit tanulmányozva veti papírra saját gondolatait, amelybỏl igen terjedelmes rész maradt ránk. Ebből a hagyatékból e tanulmány csak egyetlen darabbal foglalkozik bővebben, amely így önmagában, kiszakítva a teljes életmủből, talán nem képes megvilágítani Aranka gondolkodásának rendszerét, de bizonyos vonásokra, reményeim szerint, fel tudja hívni a figyelmet.

A terjedelmes Aranka-levelezés összegyủjtve a mai napig sem jelent meg, ${ }^{252}$ pedig fontos lett volna, hogy kiderüljön, kik azok, akiktől Aranka filozófiát tanult. İgy csak következtetésekre támaszkodhattam, Aranka kortársainak elszólásaiból derül ki az, hogy miért fordul figyelme a filozófia felé, és azt hogyan fogadja környezete. Ezeket a bölcsészeti munkákat nem szabad a filozófiai szaktudomány szempontjából megítélni. Ha lélektani oldaláról közelítjük meg Aranka bölcselkedési szándékát, lehetetlen el nem ismerni annak halálosan komoly voltát.

\footnotetext{
${ }^{250}$ Lásd. Jancsó, 1969, 265.

251 Jancsó 1947, 17.

${ }^{252}$ Azz Aranka-levelezés nagyrészét a budapesti és kolozsvári levéltárak őrzik: Budapesten az Országos Levéltár, Országos Széchenyi Könyvtár és Magyar Tudományos Akadémia kézirattára, Kolozsváron az Akadémia Levéltára és az Egyetemi Könyvtár kézirattára. Az Erdélyi Tudományos Intézet Jancsó Elemért bízta meg a levelek összegyưjtésével és sajtó alá rendezésével, de a kiadás már nem történt meg. Emiatt a tanulmányban közölt levelek részleteit más tanulmányokból vettem át, azoktól, akik számára ezek hozzáférhetöbbck voltak.
} 


\section{Előzmények a magyar irodalomban}

A kor irodalmából kiindulva, annak az ember mivoltára vonatkozó részeit vizsgálva, nem csodálkozhatunk Aranka érdeklödésének irányán. Fontosnak tartom ezeket az elözményeket felvázolni, hiszen Aranka szövegét csak ezeknek ismeretében érthetjük meg. Látni fogjuk majd, hogy eklektikus filozófiát dolgoz ki, amelyben az addig elért eredményeket feldolgozza, értelmezi, bizonyos dolgokat elfogad, másokat pedig elvet, de úgy, hogy nyilvánvalóvá váljék: tudott róluk. Ha önismereti irodalomként fogjuk fel Aranka e munkáját, akkor kapcsolhatjuk Bethlen Miklós írásához is, hiszen test és lélek viszonyára ö is rákérdez, próbálja az összefüggéseket keresni és bizonyos következtetéseket levonni. Például:

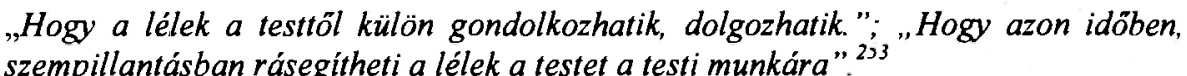

Véleményem szerint azonban ez kissé eröltetett társitás, mivel Aranka müvét csak saját korába ágyazva érthetjük meg, és Bethlennél, a testi determináció fogalmával szemben, a lélek áll kitüntetett helyen. Elég most csak Bessenyeiig visszamennünk.

Általában az ember evilági mivoltáról szóló eszmék olyan személyiségek lelkében találtak táptalajra, akik még a késöbarokk világban éltek. ${ }^{254}$ Bessenyei az elsö, aki lázadni mer, filozófusként lázad és lázadásának tétje már, kezdetektöl egy újfajta filozófia kialakitása. ${ }^{255}$ Már korai verseiben feltünik egy, a hagyományos erkölcstani nézetek filozófiai alapjait támadó gondolat: az ember testi meghatározottságának tézise. Az, hogy a testi meghatározottságú ember hogyléte nagyrészt a külsö dolgoktól függ, boldogsága csak a külvilág olyan jelenségeiböl eredhet, amelyek hatnak ránk, befolyásolják "érzékenyedésünket". (Ez a gondolatmenet Bessenyeinél $A$ Lélekrül címü verses értekezésben jelenik meg. Descartes hatása itt még közvetlenül megfigyelhetö, nála a vér legfinomabb részei a test és a lélek közvetlen kapcsolatát biztositó életszellemek.) Az elsö müveit papíra vetö Bessenyei számára nagyon sokat jelent az angol Alexander Pope Essay on Man tanítókölteménye, amelynek magyar átdolgozását 1772-ben jelentette meg. Pope egy újnak számító istenfogalmat vezet be, vagyis a Teremtỏ egy távoli lény, aki csak az univerzum nagy rendjẻvel törödik, ahol a nagy rendet a "lények láncolata" jelenti.

Aranka elfogadja és felhasználja Pope deizmusát. Bár ebben a kéziratában nem tér ki bővebben vallásfilozófiájának tárgyalására, más filozófiai tárgyủ írásaiból derül ki, hogy komolyan foglalkoztatta ez a kérdés, és Isten meghatározására különféle filozófiai irányzatok eredményeit használja fel. ${ }^{236} \mathrm{~A}$ deizmus népszerü elmélet volt a kor filozófiájában, ahogyan Szauder József rámutat, ${ }^{257}$ igen relatív helyet jelöl ki az embernek a semmi és az istenség között, és, mert a legfelsöbb rendủ állat és az ember közti különbséget szerény fokozatiságnak mutatja, magában rejti az evolucionisztikus értelmezés lehetöségét is. Aranka más filozófiai értekezéseiben ez az elmélet hangsúlyos szerepet kap (Természet Rajzolattya), ${ }^{258}$ de a kéziratos szövegben is tükrözödik abban, hogy az ember tulajdonságait mindvégig a "Plánta" és "Oktalan állal" összefüggésében vezeti le. Igencsak mélyen foglalkoztathatta ez a kérdés, mivel Fichte filozófiáját is elvetve, aki szerint legelsö, amiröl

\footnotetext{
${ }^{253}$ Waldapfel, 1980. 435.

${ }^{254}$ Ehhez lásd: Kosáry 1996. a teljes első fejezet

${ }^{255}$ Bessenyei filozófiájához bỏvebben: Bíró 1998. 74-89.

${ }^{256}$ Ehhez lásd: Aranka 1805.

${ }^{257}$ Szauder 1970. 224.

${ }^{258}$ Aranka 1810.
} 
tudomásunk van, az Én fogalma. ${ }^{259}$ az embert nem önmagából kiindulva próbálja meghatározni, hanem a természeti világgal közös tulajdonságainak tükrében.

Bessenyei hatására utal a fizikum szerepének fontossága. Bessenyei mủveiben mindvégig követhető annak a szemléletnek a hatása, amely a fizikum szerepét a szellemi tevékenységekhez képest elsődlegesnek, meghatảrozó jelentőségünek tartja. Érdemes összevetni $A$ természet világa címủ költeményének néhány sorát Aranka szövegében a 5 . Jelenés b. pontjával, ahol Aranka az anyagok különféle módon történő eloszlásảnak téziséből vezeti le az emberekben jelenlevő "csonkaságot, elmésséget, egynek egyre, másnak másra valo hajlandoságát", majd pedig a 7. Jelenés c. pontjával, ahol az erős indulatok mibenlétére keresi a választ.

Vérünk vastagsága, heve, hidegsége,

Tsendeseb folyása vagy elevensége:

Agyvelönkön futó erünk vastagsága,

Nectvessége, tüze, a vagy vékonysága,

Teszik a gondolat módját tüzesebbé,

Nehézzé, butává; avagy élesebbé. (5554-5559)

Az Ősholmiban található filozófia azonosításảhoz az istenfogalom segít hozzá. Egyfelől úgy fogják fel, mint a világ lelkét (anima mundi) - ezt a felfogást veszi át Aranka is -, másfelől pedig az univerzummal azonosítják. Arankánál is azonos az Isten a természettel, de elsősorban a természetben rejtetten mủködő, vegetatív erővel (ezt nem jelenti ki tételesen, inkább a középutat választva világlélekként jeleníti meg). Az ember azonban egyoldalúan a természet törvényeinek alávetett lẻnyként jelenik meg, viselkedését az önszeretet irányítja, a természetnek nincs erkölcsi törvénye.

Ami még összeköti Bessenyei és Aranka felfogását, a nyelv mint az ismeretterjesztés eszkőze. A Nyelvmívelö Társaság különböző felhívásaiban és program-tervezeteiben, ${ }^{260}$ továbbá Aranka leveleiben az ismeretterjesztés kérdése alapvető fontossággal bỉr. Az európai felvilágosodásnak is jellemző vonása ez. A magyar felvilágosodás írói közül különösképp Bessenyei és Aranka képviselik ezt a felfogást. De míg Bessenyei gazdálkodó magányba vonul, Aranka éppen akkor kezdi átvenni és továbbfejleszteni Bessenyeinek az ismeretek terjesztésére, a tudománynak és irodalomak a népre gyakorolt vonzerejére vonatkozó eszméit. $^{261}$ E gondolatok önmagukban véve nem újak a korban, hiszen a felvilágosodás minden írỏja többé-kevésbé hasonló mỏdon ad hangot véleményének. Ami üj Arankánál, az elsősorban e gondolatok következetes és gyakorlati vẻgrehajtásáért való harc.

Egy másik elmélet, amely hathatott Aranka gondolkodására az elterjedt fizikoteológiai irodalom. Ennek jelentősége, hogy az ember hasznára fordítandó természetkutatást sürgette, az experimentális fizika útjait és hasznosítási módját hallatlan mértékben kiszélesítette. A ráció ugyanis rendelkezésre álló eszközzé változva fóltartóztathatatlanul megmagyarázni törekszik mindent, ami tevékenységi körébe esik: a természetet éppúgy, mint az embert. Vörös Imre mutatta $\mathrm{ki}^{262}$ hogyan hódított teret a fiziko-teológiai irodalom. A természet csodálatos voltáról Istenre való következtetésnek a Bibliában gyökerező eszméje a XVII. és a XVIII. század fordulóján, a newtoni fizika eredményeinek hatására ủj történeti összefuggésben jelentkezett. Az anyagvilágnak egyre több, egzakt módon. kifejezhető törvényszerüségét sikerült fôltárni, és ennek nyomán a keresztẻny apologetika is

\footnotetext{
${ }^{259}$ Fichte, J. G. 1981.19.

${ }^{260}$ Lásd: Jancsó 1955.

26! Bár az is igaz, hogy mikor ezen az úton egyik cslódảs a másik utản éri, ô is a filozofálás magányában keres vigasztalást

262 Vörös 1991. 23.
} 
új lehetőséget látott arra, hogy a törvényszerüségek részletes bemutatásával a bölcs Teremtő létére következtessen. Fiziko-teológiai irodalmunk kezdeti szakaszában a korszerü fizika elemei sajátos módon keverednek a legkonzervatívabb tudományos elképzelésekkel (lásd pl. Pálóczi Horváth Ádám: Leg-rövidebb myári éjtszaka).

Magyarországra több irányból is áramlottak az fiziko-teológiai ismeretek. Az angol John Ray-nek és William Derhamm-nek müvei például a külföldön tanuló magyar protestánsok révén hazai könyvtárainkba is eljutottak. A maguk korában ezek igen kedvelt müvek voltak, hosszú fejezeteken át tárgyalták az emberi test felépítését és müködését, az egyes szervek szépségét és célszerüségét lépten-nyomon hangsúlyozva, a bölcs Teremtő létét bizonyított. (John Ray: The Wisdom of God Manifested in the Works of the Creation. London, 1692, William Derhamm német nyelvü fordítása: Physicotheologie, Hamburg, 1730.)

Aranka szövegével azonban sokkal jobban összeegyeztethetö az a sztoicizmusban gyökerező felfogás, amely az emberi szervezetnek éppenséggel nem egy transzcendens világra, termtő Istenre utaló tökéletességét hangsúlyozza, hanem fizikai létezésünknek a természettel való koherenciáját, az anyagvilágban való teljes feloldódás elkerülhetetlenségét.

Késöbb, ahogyan Bíró Ferenc rámutat, ${ }^{263}$ Bessenyei évtizedének mély, de szükkörü, heves világnézeti-morális lázadásait egy hasonlíthatatlanul szélesebb körü folyamat váltotta fel. Csökken az emberről való a priori tudás jelentősége a tapasztalat által nyújtott ismeretekkel szemben. Megnő az érdeklődés az antropológia iránt. Csetri Lajos szerint ${ }^{264}$ általánossá válik az antropológiai vizsgálatok tárgyának, az embernek a modern természettudományos analízis szellemében folyó vizsgálata, amely az alaposabb elemzés céljaira az emberi lelket „lélekzsákokra” (Hegel) osztva szemléli és tárgyalja. Ez nemcsak a wolffiánus pszichológiára jellemző, amely a megismerő képességet a világosabb átláthatóság kedvéért alsó és felső tehettségekre osztotta, ${ }^{265}$ módszeres tárgyalásában Kant is önálló müveket szentel az egyes emberi tehetségek alaposabb vizsgálatának.

A kor antropológiai érdeklődésének figyelemreméltó és jellegzetes dokumentuma Édes Gergely mintegy tízezer soros költeménye, A természet könyve (1790). A verses meditáció középpontjában a test és a lélek viszonya áll. Hisz az állati lélek létezésében, ugyanakkor persze az embernek az élövilág fölött való uralmát hangsúlyozva, nyomatékosan kiemeli az állatokról, hogy „Az ö párájokban nincs ítélet-tétel”, „,semmit nem okoskodhatnak". ${ }^{266}$

Először a lélektan iránt megmutatkozó s akár felfokozottnak is tekinthető figyelem ötlik a szemünkbe. Tulajdonképpen az a jelenség, vagyis a lélek válik most vizsgálat tárgyáva, amellyel korábban csak betartandó követelményeket állítottak szembe, $\mathrm{s}$ amelynek eredetére és sorsára vonatkozóan oly biztos tudással szolgáltak a vallások a kor emberei számára. A Magyar Kurír 1789 január 31 -én pályázatot ír ki egy magyar nyelvủ pszichológia megírására. A pályázat kiirásában a kor emberének érdeklődését pontosan érzékelő újságírók tájékozottsága müködött közre, $s$ a beérkezett munkák közül Horváth Ádámé (Pszichológia, az az a lélekrül való tudomámy) 1792-ben megjelent, a pályázat első diját megnyerō Bárány Péteré viszont - valószínüleg a cenzúra akadékoskodása miatt nem. ${ }^{267}$ Ez azért nagy kár, mert Bárány Kant szellemében dolgozott. Elég nyilvánvaló Arankánál is Kant eszméinek ismerete, bár ő Kant tanait Fichte közvetítésével használja. A

\footnotetext{
${ }^{263}$ Bírỏ 1998. 145-146

${ }^{264}$ Csetri 1990. 112.

${ }^{265}$ Ezt az elméletet Aranka is átveszi, de kissé át is alakítja

${ }^{266}$ Vessük ezt össze Aranka szövegével: "Az Okt.állat 's egészsz Tellyes meg fosztatott minden illyen érzéstől, ősztơntől és tehettségtől mint az Okosságok."

${ }^{267}$ Ehhez bỏvebben lásd: Gyárfás. 1990.
} 
magyar nyelvü szakirodalom a kantiánus szellem magyar nyelvterületi terjedésének kezdetét 1792-re teszi, amikor Rozgonyi József, külföldön tanuló diák hazajött, és kiadott egy latin nyelvủ munkát Jakobi és Reinhold, Kant tanítványok tételei alapján bírálva Kantot (Dubia de initiis transcendentalis idealismi Kantiani. Ad viros clarissimos Jacob et Reinhold. Pest, 1792). ${ }^{268}$ A magyar kantiánusok művei kéziratként már korábban is hatottak és terjedtek. A Kanthoz kapcsolódó magyar mủvek tartalmát meghatározta, hogy kéziratban terjedtek-e vagy nyomtatásban. A nyomtatott müvek kezdettől fogva ellene szóltak, a kéziratok pedig mellette.

Gyárfás Ágnes néhány gondolatot Horváth Ádám írásából is feltár, ${ }^{269}$ többek között azt, hogy (mint Horváth is bevallja) munkája kompiláció, a „szerző” Platón, Arisztotelész, Malabranche, Locke, Epikurosz, Hobbes és Wolff követője. Ezt a munkát valószínủleg Aranka is ismerte, és bizonyos részeit fel is használta (különösen Platón es Wolff tanait).

$\mathrm{Az}$ előzmények felvázolását Csokonai kérdéssorozatával zárom, melyek ủj támpontok keresése jegyében szólalnak meg, és túllépnek az ember redukciós szemléletén, $\mathrm{s}$ amely kérdéseket talán Aranka is feltett magának:

Ki vagy, miért vagy, hol lakol? és kinek

Szavára mozgasz? s végre mi leszel?

Mig ezt ki nem vizsgálod, addig

Por vagy, az is leszel.

(Az ember, a poézis elsỏ tárgya)

\section{Miért fordul Aranka a bölcselkedés felé?}

Az eddigi Aranka-kutatások középpontjában az Erdélyi Magyar Nyelvmívelő Társaság és Aranka viszonya állt. Müvelödéstörténeti szempontból valóban ez a legfontosabb, de ha Aranka életmüvét önmagában akarjuk vizsgálni, akkor sem feledkezhetünk meg róla ${ }^{270}$ ugyanis az a tény, hogy a Társaság éppen milyen kérdésekkel foglalkozott, Aranka munkáira is nagy hatással volt.

Jancsó a Társaság munkásságát három fö időszakra osztja. Eszerint kezdetben, 1793 és 1796 között, a Társaság fö tevékenysége a nyelvmủvelés volt; később, 1796 és 1801 között, a nyelvmüvelő program egészen háttérbe szorult, és helyét fỏként a társadalomtudományokkal való foglalkozás váltotta fel, de a bölcselet iránti érdeklödés növekedését is látjuk. Végül a Társaság életének utolsó szakaszában, 1801 és 1806 között, a természettudományok terjesztése állott érdeklödésének középpontjában. A bölcseleti gondolatok terjesztésének fontos formája volt a levelezés. 1796 és 1801 között közel másfélszáz bölcseleti tárgyú, prózában írt, tanulmányszerű levélröl tudunk. Aranka mindezeket olvasta, tudott róluk, de behatóbban az 1797-98-as évek körül kezd el foglalkozni vele. Ez különösen filozófus-költő barátjának, a voltairiảnus Fekete Jảnosnak köszönhetö. Leveleikben hosszasan elmẻlkednek a kor nagy bölcseleti és tảrsadalmi

\footnotetext{
${ }^{268}$ Ezt azért tartottam fontosnak megjegyezni, hogy rávilágítsak arra, hogy nem szükséges elhinni azt az általánosan elfogadott állítást, miszerint Aranka kizárólag Köteles Sámuel tolmácsolásában ismeri meg Kantot, bár az nyilvánvaló, hogy akkor kezd majd alaposabban foglalkozni vele

269 Gyárfás, 1990, 203.

${ }^{270} \mathrm{Az}$ Erdélyi Magyar Nyelvmívelỏ Társaság iratait Jancsó Elemér rendezte sajtó alá, a további adatokat e kötetből vettem át. Jancsó, 1955.
} 
problémáiról. ${ }^{271} \mathrm{E}$ levelezés kezdỏ éveiben még lelkesednek a felvilágosodás nagy eszméiért, hisznek a "haladás” és a ,józan ész" közeli diadalában. Később háttérbe szorulnak a francia felvilágosodás eszméi, egyedul Voltaire hatása erős még. Ekkoriban is föleg Fekete Jánossal áll kapcsolatban, de leveleket vált Dessewfty Józseffel és Sipos Pállal is.

A Társaság filozófiai érdeklődésének középpontjában is az antropológiai, etikai és nevelési kérdések állnak. Aranka a XVIII., 1796 július 12-én tartott gyülésen mondott beszéde is utal arra, hogy a Társaság a nyelvmüvelésen kívul más dolgokkal is fog foglalkozni:

„Eljövén $a z$ az idô, hogy kötelességünk szerint való munkáinknak terhétöl szabadulván, egy kis idônket a szép tudományokra is csendességben $s$ elménk nyugtatásával fordithatjuk".

Ezen a gyülésen azonban a felolvasott tizenkét munka közül még csak egy antropológiai témájú, $A$ brassai vadember, amely Kazinczy Orpheusaban is megjelent 1790ben. A Társaság iratai között később ilyen és ehhez hasonló cimü irások találhatók: $A z$ emberi lélek halhatatlansága, $A$ bölcselkedés elvei,Erkölcsi nevelés leckéje.

A Társaság iratai szerint Aranka az 1797 április 24-i gyülésen felolvas egy „gondolatocskát" az emberröl, amelyröl valószinünek tartom, hogy egy korábbi változata az általam vizsgált kéziratnak, hiszen akkor még nem lehetett olyan széleskörü filozófiai ismerete, mint amelyröl ez a kézirat tanúskodik.

Pope-nak az emberröl irt leveleit is leforditja a Társaság valamelyik tagja, ezt Aranka kiadásra is bocsátja, tehát a „létezök láncolata"-elvet nem csupán Bessenyeitöl ismerhette, és valószinüleg deizmusára e forditás is hatással volt.

$\mathrm{Az}$ ismeretelméleti problémákkal való foglalkozás már inkább a Társaság munkásságának harmadik szakaszához füződik, amikor Köteles Sámuel széleskörủ filozófiai érdeklődést ébreszt a helyi értelmiség soraiban. Az idős Aranka is véndiákként hallgatja elöadásait, és aztán éveken át Kant és a német bölcselet tanulmányozásában merül el. Barátait leveleiben filozófiai kérdésekkel ostromolja. 1801. szeptember 12-én írja Feketének:

\section{„Miért élünk, barátom? Ezt a kérdést senkisem fejtette meg."}

Azok, akik tudtak bölcseleti munkảióbl, épp olyan csendes gủnnyal szólták le értekezéseit, mint verseit. Kazinczy így ír 1811 szeptember 12-én Cserey Farkasnak:

„Szegény öreg Aranka túlélte magát, nagy kár, hogy el nem némult."

Sipos Pál pedig Kazinczynak 1814 június 12.én:

„Marosvásárhelyi korespondenciám elszünt Aranka úrral. Ö se ért engem, én se öt. [...] Mit tegyen az Én, Te, Ö, philosophice magyarázta és végre kérdé Naláczyt, mint veszi a dolgot? Ez igen mély dolog barátom, mert ezt Én se értem, Te sem érted, $\bar{O}$ sem érti."

${ }^{271}$ Az Aranka-Fekete levelezés 58 levélből áll, ezek a Magyar Tudományos Akadémia valamint a Román Akadémia kolozsvári levéltárában találhatók. 
Aranka azonban ezekkel nem törödve, szorgalmas diák módjára mutatta meg munkảit Köteles Sámuelnek. Meglepő, hogy Köteles kritikus hozzáállása sem készteti meghátrálásra. E kritika mérsékelt volt ugyan, de nem mellözhető. Köteles Sámuel így ír egyik munkája hátlapján:

„A Méltóságos úr munkájában azt tapasztaltam, hogy a Méltóságos úr a tiszta okosság útján indult, és az embernek esméretét ezen az ủton próbálta megmagyarázni. [...] Nem találom a szisztéma tökéletes és való egységét."

Talán Aranka sem tartotta ezt túlságosan rosszalló megjegyzésnek, ezért folytatta bátran tovább elmélkedéseit. 1805-ben ${ }^{272}$, majd pedig 1810-ben ${ }^{273}$ jelentette meg filozófiai tárgyú írásait.

A világot a "Sok" és az "Egy" viszonyában, a változó és az örökkévaló maradandó egységében ragadja meg munkáiban. Az 1810-ben megjelent mủben emlitést tesz arról, hogy az Ember Esméretét már korábban megírta, de "még Világot nem látott", és szándékában áll ezt is kiadni, hogy filozófiai rendszere teljesen kidolgozott legyen. Tudomásom szerint ez nem történt meg. A magyar bölcselet történetében Aranka nevét alig ismerik, ha szólnak is róla, ez csak negatív értelemben történik, pedig azt érdemei közé sorolhatnánk, hogy az első magyar kantiánusok közé tartozott. Pozitív értelemben egyedül Erdélyi János beszél róla ${ }^{274}$ :

"Kant után a bölcseletnek két útja állott nyitva európaszerte. Az eszmei út követése hamar nyilvánvaló lett irodalmunkban. Erdély, hol a gondolkodó, mert költői alig voltak Erdélynek, oly rég idők óta lel kedves tanyát, valamint Cartesius korában Apáczai Cserével, úgy Fichtében is megelözte Magyarországot Sipos Pál és Aranka György bölcsészeivel."

Ennyi méltatás talán elég is lett volna Arankának ahhoz, hogy gondolatait rendszerezze, s kidolgozva bocsássa olvasói rendelkezésére.

\section{A kéziratról}

A kolozsvári Egyetemi Könyvtár Aranka gyüjteményében az Ember Esmérete cím alatt négy kézirat található. Egyik biztosan Aranka György autográfiảja, egy másik Zsombori József írása. ${ }^{275} \mathrm{~A}$ másik két kézirat ${ }^{276}$ íróját nem tudtam felfedni, de valószínủnek tartom, hogy ezek is Aranka György munkái, másolóinak kezeírásában. Ezt azért gondolom így, mert Benkő Loránd is említi, hogy Aranka másolói híven adták vissza helyesírását, ${ }^{277}$ valamint a szövegekben vannak olyan részek, amelyek túlságosan hasonlóak egymáshoz, így nem feltételezhetjük, hogy ezeket három kủlönbözỏ személy írta. Ennek bizonyítására hozom fel a következỏ példát:

\footnotetext{
${ }^{272}$ Ember Világ Isten, egy Philosophiai elmélkedés.

${ }^{273}$ Két Elmélkedés.

${ }^{274}$ Erdélyinek 1857-ben Sárospatakon jelenik meg $A$ hazai bölcselet jelene címủ mủve.

${ }^{275}$ Zsombori József kézírását egy általa írt és aláirt levéllel való összehasolításból állapítottam meg. Zsombori József Marosvásárhelyen volt kanonok

${ }^{276}$ E két kézirat nem kizárólag az ember Aranka felfogásában vett "esméretével" foglalkozik, és mindkét kézirat hiányos.

${ }^{277}$ Benkỏ 1960. 123.
} 
1. kézirat:

Hogy az Ember, mint

Ember Elsöbenn ollyan

Egy és Sok hogy a'

Soknak nincsen

Középpontya, csak köz

pontya és a' Sok közül

mindenik az ö Nemének

ugyanazon

tulajdonságaival bir

mint a' Másik, és azért

a' központ a' Sok közül

mindenikben ugyanaz

lévén, annál fogva a'

Sok siet és vonszodik

egy máshoz.
II. kézirat:

A' csupa Nem ollyan

Egy és Sok, mellynek

egységének csak köz

pontya vagyon, közép

pontya pedig nincsen. $A^{\prime}$

Soknak nincsen közép

pontya, mellyhez

siessenek,

vonszodjanak: hanem $a z$

mindenikben ugyan az 's

egész lévén egymáshoz

sietnek, vonszodnak.
Végsổ változat:

Az emberenn kivül, teli

találom nemmel az egész

Tellyest. Hig, folyo,

repülö, ércz, $a^{\prime}$

testeknek vékony Eleji

mind csupa és tulajdon

Nemek. Közép pontyok

nincsen csak köz

pontyok: minden szem

bennek maga Nemének

egészsz tulajdonságaival

bir; és maga Neme más

részeihez vonszodik.

Ezért a továbbiakban e két kézirattal nem foglalkozom, hiszen a végső változat az „ember esméretére” nézve e két anyagot szinte teljességében tartalmazza. Eredményre vezet, ha megvizsgáljuk a Zsombori- és Aranka- szövegek közötti összefüggéseket. Aranka nem említi, hogy saját rendszerének kidolgozásában felhasználta volna Zsombori gondolatait. Zsombori szövegében már szinte minden jelen van, ami később Arankánál megjelenik. Azonban nem kell Arankát túlságosan elítélni azért, hogy átveszi, és magáénak vallja ezeket az eszméket, mert ez így csak részben igaz. Zsombori szövege nem teljesen világos, részmeghatározásokat ad, és nincs kellöképpen rendszerezve. Aranka viszonylag jól megértette az írottakat, és javitásain látszik, hogy másoknak is érthetővé tudta tenni. Mivel ebben a dolgozatban nem áll szándékomban összehasonlító elemzést végezni a kẻt szöveg között, csak az általam legfontosabbnak ítélt átvételeket említem meg, bár az sem nyilvánvaló, hogy ezeket Zsombori szövegéböl ismerte meg és vette át Aranka, mivel a kor filozófiájában ezek a bölcselkedök között ismert nézetek voltak, legtöbbjük Wolff-tól, Kanttól és Fichtétöl származik. Ezekre az elemzés során utalni fogok.

Szólnom kell még néhány szót Aranka írásmódjáról. Mivel véleményem szerint ezt a végső változatot Aranka 1797 és 1809 között kẻszítette el, ${ }^{278}$ Kazinczy állandó bírálata hatására a nyelvi provincializmusok csökkenő számát, és ezzel együttjáróan az írásnak az irodalmi nyelvi forma felé való közeledését mutatja. ${ }^{279}$ Aranka csak az á-t és é-t ékezi következetesen vesszövel (bár néha ezt is elfelejti), ü-t és ö-t keveset és nem tudatosan használ, í-t, ó-t és ú-t egyáltalán nem is használ kéziratában, hanem helyettük a megfelelö rövid változatokat alkalmazza; sz helyett $\beta$-t használ, $s$ helyett néhány helyen $\mathrm{f}-\mathrm{t}$, és következetesen használja az ő kézírására jellemzö ragoknak megfelelö jelet.

${ }^{278}$ Ezt onnan vezettem le, hogy bár 1797-ben felovassa értekezését az emberröl, de a végsö változathoz mindenképpen ismernie kellett Kant filozófiáját, ezt pedig 1801 utản, Köteles Sámuel előadásaiból sajátította el. Hogy 1809 elött már befejezhette, onnan gondolom, hogy Zsombori, levelében két olyan általa feltett kérdésre válaszol, melynek elözményei ebben a tanulmányban keresendők. A két kérdés:"Mi az a' Mi, mellyet az Ember üz, és a ' mellyre a' Természettôl hajtatik? A' mibỏl és miben áll? Az a tökéletesség ábráyattya po. mellyet akkor ér el, mikor az ô kifejtỏdésének tellyes mértékit eléri, millyen?", "Annak a' Minekformálhattyaé gondolatját vagy nem?"

${ }^{279}$ Ehhez bővebben lásd: Benkő, 1960. 


\subsection{A kézirat elemzése}

Aranka pontos definíciót akart keresni az emberre. Az írás tudatos retorikus igénnyel készült, pedig, amint Csetri Lajos megemlíti ${ }^{280}$ a korszak Magyarországán egy nyelvesztétikaibb színezetü retorikai szemlélet hiánycikk volt. ${ }^{281} \mathrm{~A}$ szöveg (néhol meglehetősen aránytalanul) éppúgy magában foglal természettudományos ismereteket, mint szigorú értelemben vett bölcseleti gondolatmenetet. Serkentő és befolyásoló tényező a karteziánus racionalizmus lehetett, amely nagy hangsúlyt fektetett a fogalmak világos és egyértelmü maghatározására, illetve a deduktív módszerre. Bár a megismerést mint olyat, igyekszik Kant és Fichte szellemében vizsgálni, nagy hangsúlyt fektet a megismerésnek a megismerő alany oldalán jelentkező feltételeire is. A megismerő ember csak jelenségeket foghat fel, ilyen értelemben tudása tapasztalati. A szöveg első mondatában érezhetö már Kant hatása, amely szerint a megismerés az érzéki észlelés (Arankánál: az emberen kivül), valamint az éretelmünk (benne is találod az emberben) spontán müködésének a szintézise, amit később majd Aranka is levezet. Mindent Jelenésként lehet szerinte megismerni, és ez a jelenés emberi és természeti tulajdonság. Először megpróbálja elhelyezni az embert az univerzumban. Tételes kijelentése, hogy „az ember Nem”, „minden ember ez alá tartozik". ${ }^{282}$ Lendvai L. Ferenc Fichte írásainak előszavában fejti ki, hogyan járult hozzá Kant és Fichte ahhoz, hogy az egyénről a hangsúly az emberi nemre tevődjék át. Már Kant rámutatott arra, hogy saját létünk tudatával egyszersmind a rajtunk kívüli dolgok tudata is adva van, ${ }^{283}$ ez Fichte átértelmezésében úgy jelenik meg, hogy a cselekvő Énnel együtt már adva van a nem-Én is, mint az Én tevékenységének tárgya. ${ }^{284}$ Létezik tehát egy szubjektum-objektum viszony. Én és nem-Én ellentéte egy abszolút Énen belül jön létre. Egy abszolút, tehát nem egy esetleges, egyéni Énen belül. Ezzel Fichte, továbbfejlesztve a kanti „általában vett tudat" gondolatát, fontos lépést tett azon az úton, melynek során az egyén helyére filozófiai szubjektumként végül az emberi nem lépett. Ezt használja fel Aranka, s nagyon fontos, hogy ezt az elvet tekinti kiindulópontnak. A tovảbbiakban élesen elhatárolja egymástól a Középpontot és Köz pontot. Analógiát ảllít fel a Tellyesben található Nemek és az emberi Nem között, melyeknek közōs tulajdonsảga az, hogy ,saját Neméhez vonszodik". Csak burkoltan, de megjelenik Newton gravitáció-elmélete is:

\section{„mint a' Naphoz a' körüle járo több aprobb csillagok vonattatnának”.}

Aranka kitér az individuum szerepére is, de az egyénnek tartalmaznia kell nemének tulajdonságait. Egyfajta örömmel nyugtázza, hogy ember és természet között hasonlóságot tud találni, és a továbbiakban e hasonlóságot véve alapul, az embert s mikrovilág részeként az univerzummal, a makrovilággal szembeállítva tárgyalja.

$\mathrm{Az}$ ember azonban társadalmi lényként is felfogható, olyan lényként, aki önmagán kívül más individuumokat is feltételez (ez a gondolat Fichténél is jelen van), ezekkel kapcsolatban áll. Individuumként természetesen minden ember egyedi, de bizonyos hasonlóságokat feltételez azon személyek között, akik valamilyen társaságban együtt élnek. Ez utalhat arra az általánosan elfogadott psszichológiai nézetre, hogy az ember

${ }^{280}$ Csetri, 1990. 54.

${ }^{281}$ Ha valaki latinon kívül valamilyen modern világnyelvet is ismert, hozzáférhetett korszerübb, esztétikaibb megalapozottságú retorikai és stilisztikai rendszerekhez is. Magyarul azonban elöször Révay irt retorikát, és az sem jelent meg.

${ }^{282}$ Zsombori szövegében az ember Nem. Alkotvány és Alkotványi Nem.

${ }^{283}$ Aranka más filozófiai tárgyủ íásaiban ez úgy jelenik meg, hogy az Én, Te, Ö viszonyából próbálja levezetni az egész Tellyest.

${ }^{284}$ Fichte, $1981 \mathrm{~b}, 134$. 
viselkedésmódját mennyire meghatározza az öt körülvevő környezet. Tudomása van elödeiröl és eljövendő utódairól is, kapcsolatban illetve relációban áll velük, ahol a reláció vagy viszony az, amit úgy gondolunk el, hogy az az adott dolgot egy másik dologgal együtt illeti meg. Reláció van például atya és fia között, vagy az emberi test, és a Tellyesben fellelhető más testek között. Az emberek közötti viszony azért lehetséges, mivel származásuk ugyanaz. Ezekkel Aranka megfogalmazásában nagyon bensőséges kapcsolatban áll, mindeniknek „sorsát érzi”. Az intenzív érzelem gondolatát Rousseau-tól vehette; olyan érzület, mely arra késztet, hogy az embertársunk helyére képzeljük magunkat, és Rousseau szerint ez az érzés eleven a vademberben, kitisztult, de gyenge a civilizált emberben. Ebböl a tételböl vezeti le Aranka az alkotvány fogalmát, bár pontosan nem határozza meg mit ért ezen. Az ember különbözö anyagokból épül fel, s ezek valamilyen módon összeköttetnek, de ebben a részben még nem jelenti ki, hogy mindez az értelemnek kőszönhető. Annak ellenére, hogy az embernek vágyai és követelései alapján függetlennek kellene lennie a természettöl s egyáltalán minden törvénytől, melyet nem ő ad magának, Aranka vizsgálódása szerint az ember teljességgel meghatározott láncszem a természet láncolatában. Néhol még Kant is elképzelhetönek tartja, hogy nincs szabadság, hanem minden a természet törvénye szerint müködik. Aranka teljességgel elfogadja ezt az elvet, és az embert a Plánta és Oktalan állat mellett tételezi, nincs közöttük túl nagy különbség:

„, Mindenik egy kicsiny csirábol lassan lassan fejtôdik ki, él, és élni meg szünik: de maga utánn, maga Nemének más Képviselójét állittya bé maga hellyett."

A testi világot alkotó elemek mindegyikének megvan a rá jellemző meghatározott képessége és minösége, ami megszabja, hogy melyik mire képes, és melyikböl mi lehet. S ami ezekböl a kezdetekböl megszületik, az mind saját fajtájára jellemzö idöben jön létre, fejlödik ki, s jut el a megsemmisüléshez is. A hím és nőstény egyedben található különbözö természeti erök (a hímben a „Nem forma erö" és a nőstényben az „alkotványi erő”285) révén történik a szaporodás. Fichte is kidolgozza filozófiájában ezt az elvet, ${ }^{286}$ miszerint egy általános természeti erő határozza meg az ember létrejöttének idejét és azokat a tulajdonságokat, amelyekkel az ember létrejött; ugyanez a természeti erő határozza meg mindazokat az alakulatokat, amelyek között e veleszületett alaptulajdonságok megnyilvánulnak és meg fognak nyilvánulni, ameddig az ember létezni fog. Ha ez nem így lenne, akkor egyáltalán nem történhetne meg az utódnemzés, hiszen szükség van egy bizonyos különbözőségre ahhoz, hogy a hím szerethesse a nőstényt. Aranka még az ember esetében is teljesen kizárja az érzelmek szerepét, ez a folyamat kizárólag a természet törvényei útján történik. A növény természeti rendeltetése, hogy szabályszerüen kialakuljon, az állaté, hogy célszerüen mozogjon, az emberé, hogy lelkében kifejlödjenek a megismeréshez szükséges eszközök: az esmérő és érző tehetségek. Az emberi megismerés két forrásáról szóló tan, ahol is a két forrás (bár egymáshoz rendelődik) meglehetősen független egymástól, olyan hagyományos bölcseleti álláspont, amely legalább Platónig nyúlik vissza. Antropológiai eredetủ, a test-lélek dualista felfogása fejeződik ki benne.

Mint már elözőleg említettem Édes Gergelyröl szólva. létezett egy olyan felfogás, amely szerint az állatoknak is van lelkük ${ }^{287}$ Aranka is hisz ebben az elméletben, az ö felfogása, hogy az élölényekben egyetlen világlélek mủködik. E felfogásnak elözményei között a sztoicizmus nyomokban éppúgy felismerhető, mint az újplatonizmus.

${ }^{285} \mathrm{Ez}$ Zsomborinál is ugyanilyen módon kifejtve jelenik meg.

${ }^{286}$ Fichte, $1981 \mathrm{~b}, 252$.

${ }^{287}$ Bod Péter bibliai lexikona "lelkes állat"-on az "okosság nélkül való állatok"-at érti, "a' mellyek a' természetnek indulatját követik a magok tselekedeteiben" 
A materializmus az embert körülvevő objektív tapasztalati tényekböl indul ki, az emberi tevékenységet azonban a valóság befogadásának és elfogadásának passziv szerepére korlátozza. Vagyis az ember kénytelen elismerni azt a tényt, hogy nem változtathat nemének tulajdonságain, aláveti magát azoknak a törvényeknek, amelyek szerint nemének tökéletességét el nem érheti. Platón Idea-tana a későbbiekben is megjelenik majd Arankánál, de ebben a részben is nyilvánvalóvá válik, hogy ismerte és filozófiájában felhasználta. ${ }^{288}$ Vagyis az emberi tökéletesség csak az ideában lehet jelen, egyetlenegy földi egyed sem érheti ezt el. Érdekes, hogy a növényeknek és állatoknak megenged egyfajta tökéletességet, ezt azonban nem szabad összetévesztenünk az idea tulajdonával. Ha egy növény vagy állat megfelel saját neme követelményeinek, nevezhetjük tökéletesnek, de ez a tökéletesség mindig ugyanaz marad. Furcsa evolucionisztikus elméletet fejleszt ki Aranka. Egyrészt tagadja a változást:

"kezdettôl fogva végig nyomrol nyomra Képviselöiben változik ugyan: de Neme 's alkotványi formájára nézve ugyan az marad."

Ennek a ténynek fontos megkülönböztető funkciója van az ember valamint a növényés állatvilág között. Mert, ettől eltérően, az ember esetében, az egyén nem érheti el soha a tökéletességet:

"ellenben a' Nagy alkotvány nyomrol nyomra fejtôdik, 's az tökélletesedik."

Nem elég nyilvánvaló, hogy hogyan érti ezt a fejlödést Aranka, azonban ha más filozófiai írásai is eszünkbe jutnak, azok melyek nyomtatásban is megjelentek, emlékezhetünk, hogy az egyikben kidolgoz egy olyan elméletet, mely szerint az emberiség végső szakaszában el fogja érni a tökéletességet, s akkor a fejlödés teljesen meg fog szünni. A tökéletesség fogalmából vezeti le a boldogság definíciójảt. Ehhez egyfajta keresztény etikát is felhasznál, de nem kizárólag azt. Fontosnak tartja a lẻlek fogalmának bevezetését. Még semmilyen különösebb funkciót és tevékenységet nem ruház rá, teljesen hagyományos keresztény értelemben tekinti a lelket, amelynek ,sẻrelem nélkül és ártatlanságbann való tartása és megbecsüllése" révén érheti el az ember az erkölcsi tartását. Egy lehetséges forrása a boldogságnak a sztoikus életforma, a sorsba való beletörödés, a világ menetébe való belenyugvás, a szenvedélymentes élet, szigorú erkölcsisẻg, bölcs belátáson alapuló szilárdság. Másik fontos összetevője a boldogságnak az önszeretet. Aranka ezt Rousseau-i értelemben használja, tudniillik nem szabad összekeverni az önzés és az önszeretet fogalmát: e két szenvedélynek ugyanis igen különböző a természete és a hatása. Az önszeretet természetes érzelem, amely minden állatot arra késztet, hogy önfenntartására ügyeljen. Az emberben az önszeretetet az értelem és a szánalomérzet modifikálja, eképpen születik az emberség és az erény.

Végkövetkeztetéseket von le ezekből: az ember ismerete két fö összetevőböl áll, egyik az ember testi meghatározottsága, amely öt beépíti a természet rendjébe, másik az emberi boldogságban rejlik. A testi felépítést a továbbiakban mellözi, figyelme ezek után az ember megismerő tevékenységére összpontosul. A megismerő képességet Esmérő tehettségnek nevezi. Leibniz és Wolff az esméret tehetséget alsó és felső tehetségekre osztotta, az alsó tehetségek szerintük az, amivel a barmok és a csecsemök rendelkeznek:

\footnotetext{
${ }^{288}$ A korban Platón tanai föleg Boethiuson keresztül hatottak. Orczy Lỏrinc szerint a "Tudósoknál olly betsbenn tartatik, hogy ritka ki ne olvasta volna." Orczynak ez a megállapitảsa arról tanúskodik, hogy a Boëthius által (is) közvetített platóni világkép a XVIII. század magyar olvasói elött sem volt ismeretlen.
} 
képet alkotnak, van képzeletük és emlékezetük. Aranka ezeket a tehetségeket a külsỏ és belső érző eszközökkel kombinálja, így nála a megismerỏ képesség négy összetevőből áll: Külsö, Belső, Középalso és Közép felső alkotványból. A külső eszközök az érzékszervek (a látás és hallás nemesebb, mint a többi), a belsőkkel pedig a gondolkodást azonosítja. A test és lélek viszonyára tér ki még egyszer bỏvebben. Már Hatvaninál is megjelenik a corpusbỏl és animából álló ember teóriája, ${ }^{289}$ de az ő elméletét, amely szerint a megismerés képességét az Isten adja ugyan az embernek, de az ideákat az elme alakítja ki saját múködésével, Aranka tovább fejleszti és pontosabban értelmezi. Aranka a lélekben feltételezi az a priori tudás székházát, és ebben az elméletben elszórtan még Descartes néhány gondolata is megtalálható. Descartes szerint ugyanis az embert gondolkodó lelke emeli a gépszerü állatok fölé. Benne a gondolkodás és kiterjedés egyszerre vannak meg. Az élet központi szerve a szív. Az életszellemek a vérből válnak ki, és ők az összekötő szervek a szív és a lélek között. Az egyvelöt tekinti a lélek színhelyének. ${ }^{290}$ Arankánál az újplatonikus örökséget felhasználása következtében erős a hajlam arra, hogy az embert lelkével azonosítsa, és szellemi természetet tulajdonítson neki. A lelket kizárỏlag önmagába véve szemléli:

„Egyik fö tehettsége a' Léleknek a' Nemforma erô, az esmérō tehettség; ez csak tehettség, ez magában a világonn semmivel nem jöhet közôsủlésbe, más Lélekkel se jőhet költsönös munkába. "29I

\section{Érdemes ezt a definíciót összevetni Horváth Ádám lélek-meghatározásával:}

„A Lélek egy személyes, de testtel öszveköttetett valóság, mely érzékenységek által érez, a maga erejébỏl képez, a testet eleveniti, gondolkozik ..."

Aranka a lélek megismerö és fogalomalkotó szerepét Kant és Fichte elmélete szerint próbálja megmagyarázni, de kissé homályos, nehezen érthetö ez a rész. Kant és Fichte szerint egy teljes képzethez háromféle dolog kell: az, ami által a képzet valamely objektumra vonatkozik és valaminek a képzete lesz, amit mindketten érzéki szemléletnek neveznek; az, ami által a szubjektumra vonatkozik, és az én képzetem lesz (amit Kant nem nevez szemléletnek), végül pedig az, ami a kettöt egyesíti, amit fogalomnak neveznek. Ez a léleknek a tárgyi megismerést meghaladó kvalifikált tevékenysége, mely a belső érzỏ eszközök segitségével fejti ki hatását.

Aranka okfejtése minduntalan elakad a megismerés két alapforrásảnál. Úgy tủnik, azt az alapmeghatározást, amelyet Kant nagy müvének bevezető gondolataiban tár az olvasói elé, még megérti:

"Bevezetésül és figyelmeztetésül csak az látszik szükségesnek, hogy az emberi megismerésnek két törzse van, mely talán közös, de elöttünk ismeretlen gyökérböl

\footnotetext{
${ }^{289}$ Hatvani, 1990, 16.

${ }^{290}$ Nem fogadja el azonban Descartes racionalizmusát. Ha elolvassuk a következő idézetet láthatjuk mennyire más nézeteket képvisel Aranka. "Eleddig mindent a legnagyobb mértẻkben igaznak tartottam, akár az érzékelésbōl, akár az érzékek útjản tettem szent ismeretükre. Közben azonban megértettem, hogy ezek becsapnak - és okos dolog sohasem hinni abban, ami akár csak egyszer is becsapott."

${ }^{291}$ Már Szent Ágostonnál is megjelenik az a felfogás, hogy a boldogságot a léleknek önmaga megismerésén keresztül kell keresnie. Az így értelmezett boldogságkeresés lesz a filozófia feladta, amely tudomány két tárgya Ágoston szerint az emberi lélek és az Isten
} 
ered, ti. az érzékiség és értelem, melyek elseje által tárgyak adatnak, másodika által pedig gondoltatnak.",292

Az nem világos számára, hogy ez a két alapforrás egymásra van utalva. Pedig Kant ezt is világosan kifejti:

„Érzékelés nélkül nem lenne adva számunkra a tárgy, értelem nélkül pedig nem gondolhatnánk el azokat. A gondolat tartalom nélkül üres, a szemlélet fogalom nélkül vak. "293

Azonban, és ezt nem érti igazán Aranka, mindig világosan meg is kell különböztetnünk öket egymástól, hiszen az értelem semmit sem képes megszemlélni, az érzékelés pedig semmit nem képes elgondolni. Mivel a megismerő ember a megismerés folyamatában minden dualitás ellenére egy és ugyanaz, igen különös, ha valaki megelégszik azzal, hogy megadja az emberi megismerés két, egymástól különböző mozzanatát anélkül, hogy alaposabban utánajárna egységüknek. Nem teljesen Aranka hibája ez, hiszen Kant empiriája is mindig jelenségekhez kötődik, amelyeket az észre nézve bizonyít. A belső tapasztalat elözményeként elfogadja a tárgyi világból eredő külső tapasztalat elsőségét, de a kettöt egymás okának már nem ismeri el. Mindkettőt megelőzi a „belső érzék jelensége”, s igy mindkettő ennek okozata. ${ }^{294}$

Aranka ezekröl a szigorú értelemben vett filozofikus gondolatokról, amikor úgy érzi, megakadt, játszi könnyedséggel ugrik át saját spekulációira (például arról, hogy miẻrt vannak az emberek különbözö adottságokkal ellátva).

Figyelemre méltó, hogy olyan megállapításokhoz jut el, mint az, hogy a különbözö anyagok különbözö módon való keveredéséből következik az embereknek különféle dolgokra való hajlandósága. Néha Aranka szertelenségének köszönhetően elég nehéz követni a gondolatmenetet. Elmélkedéseit ott hagyja abba, ahol azok érdekessé kezdenek válni, s egy-két alpont után folytatja gondolatait. Miután például a 4. Jelenésben felosztja a megismerỏ képesség alkotványait négy összetevőre, csak a 6. Jelenésben magyarázza meg, hogy mit ért ezeken. Tehát nála a Felsỏ alkotvány az érzékszerv, de az érzékszerv müködésbe hozása a Külső alkotvány munkája. Az érzékszerv belső, élettani müködése a Középalso alkotvány dolga. A gondolkodásnak a Belső alkotvány, a képzelgésnek pedig a Közép felső alkotvány felel meg. Ez a Közép felső alkotvány a legfontosabb, mivel ez teszi lehetővé, hogy némely képzetek úgy jelenjenek meg az ember előtt, mint amelyek teljesen az ö szabadságától függenek. Lehetetlenség azonban azt gondolni, hogy megfelel nekik valami, ami az emberen kivuül és az ő közremüködése nélkül létezik. Képzelete, akarata szabadnak jelenik meg minden ember elött.

A megismerés, mint Hatvaninál is, a perceptioval kezdődik. Ez az észrevétel, amely az érzékelésből indul ki, s az ideához jut. Az idea itt fogalom értelemben veendö. Ehhez elözetes feltételként szükség van a lélek a fentiekben már felvázolt szabályszerü müködésére. Kant szerint a gondolkodási képesség a szisztematikus megjelenitésben három tagból áll: az elsö az értelem mint kẻpesség az általánosnak (a szabályoknak) a megegismerésére, a második az ítélőerỏ mint az a képesség, amely a különöst az általános alá szubszumálja, a harmadik pedig az ész mint az a képesség, amely a különöst az általános által határozza meg. ${ }^{295}$ Lássuk, hogy jelenik ez meg Arankảnál. Mint már említettem, a megismerés az észrevétellel kezdődik. A látás Aranka elméletében központi helyet foglal el.

\footnotetext{
${ }^{292}$ Kant, 1913. 34.

${ }^{293}$ Kant: i.m. 75.

${ }^{294}$ Kant: i.m. 358.

${ }^{295}$ Kant, Az itélöerö kritikája.én. 23.
} 
A látás meghatározásában igazi kanti ismeretelméleti elhatárolás történik, annak ellenére, hogy nem használja a kani terminológiát:

„po. a' Szemnek adatik egy Élófa. Ezzel két pont adattatik: egyik a' nagy látás egészsz határozattya, erdô, mezô, hegy sat. Másik az egy, az Élôfa benne. Veszem az utolsót, a' fát például; abban vagvon $a^{\prime}$ mi Néked nemadattatik: ez a' dolog magában. nincsen külsổ esmérete. Vagyon a' mi adatik: és ez a' mennyiben a' fára vitetik a' Jelenés. a' mennyiben Reád a' Látás. " (kiemelés B. A.).

Úgy tủnik, Aranka megértette a Noumenon-Phenomenon viszonyát, s ha csak ennyit megértett a kanti filozófiából, már akkor sem tartom helytállónak Kazinczy és köre állandó jellegü gúnyolódásait. Horkay is megemlíti, ${ }^{296}$ hogy a korban kevesen tudtak szakszerü definíciót adni e két fogalomra, egyetlen kivétel Márton István debreceni tanár volt. Ő így határozta meg e két fogalmat:

Noumenon - Igy neveztetik a Critica Filosofiában az ollyan magában lévố dolog, a mellynek semmi Relatioja nincs az én Esmérettehetségemmel.

Phenomenon - Az ami az én Testiségemnek s tapasztalhatásomnak tárgya lehet.

Aranka ezt ugyanilyen értelemben használja, és további nézeteit ebből vezeti le. Legfesöb szinten az Esméret áll, minden más tevékenység ennek van alávetve. Észrevétel, Képzelés és Tudás, e három összegzéséből keletkezhet az ismeret. Ennek az ismeremek három fö iránya lehet: egyik az önismeret, másik a világ ismerete, harmadik pedig a lelkiismeret. Kant nyomán jut el a belső tudat olyan képességéhez, mely a külsỏ empirikus észlelés segítsége nélküli önismeretet tételezi fel. A kẻpzelőerő nagyon fontos, az a tudat kontrollja, mivel az, hogy vagyunk, az Én számára nem lehet empirikus tapasztalat, csak a képzelet segítségével tudatosithatja a tiszta ész. Fichte szerint is minden tudat az öntudaton alapul és az öntudatot feltételezi. ${ }^{297}$

Aranka a továbbiakban is mindenre nagyon pontos definíciót akar találni. Az önkéntség és akarat fogalmai állnak a központi helyen. Fichténél az akarás nem egyéb, mint valamelyik belső természeti erőnk müködésének közvetlen tudata. Ha ennek az erőnek a törekvése még nem hatékony, mert ellenkezö irányba törekvő erők gátlás alá helyezik, e törekvés közvetlen tudata mint hajlandóság vagy kívánság jelenik meg a tudatban. ${ }^{298}$ Arankánál is hasonló az akarat müködésének leírása:

„érzékenyedik az Érzô alkotvány, és a’ kivánság, szükség, ösztön, mintegy also, végre hajto Tábla, igyekeznek azt a' Mit mint Czélt végre hajtani. Ebben az egész munkábann pedig az a' középpont, az $a^{\prime}$ köz tehettség melly $a^{\prime}$ Határozást $a^{\prime}$ kivánságra mint czélt által viszi: az Akarat."

$\mathrm{Az}$ ítéletet is meg kell határoznia, itt Aranka elmélkedése ismét Hatvani filozófiájảhoz áll közel. Hatvani szerint ugyanis ítélni annyi, mint két ideát egymással kőlcsönösen összehasonlítani, és megvizsgálni azt a viszonyt, amely a kettỏ között fennảll: hogy megegyeznek-e, vagy eltérnek egymástól. ${ }^{299}$ Arankánál az ítéletnek hasonló funkciója

\footnotetext{
${ }^{296}$ Horkay László: Kant elsõ magyar követõi = Irodalom és felvilágosodás (szerk. Szauder József Tarnai Andor) 1974. 205.

${ }^{297}$ Fichte: $19816,65$.

${ }^{298}$ Fichte: i.m. 262.

${ }^{299}$ Hatvani István: i.m. 51.
} 
van, de külső ítéletek meghozatala mellett inkább a belsöre koncentrál, és a helyes viselkedés normáit határozza meg, a lelkiismeret tulajdona.

Aranka minduntalan visszatér az oktalan állattal való összehasonlításra. Elméletében végre eljut addig a tényig is, hogy az embert az határolja el az állattól, hogy gondolkodik, Maga tudással rendelkezik. Az Én-tudattal rendelkező ember, bárhogy értette Aranka ezt az öntudatot (etikai vagy fiziológiai értelemben), a személyiség privilégiuma. Ez az elöjog az emberi nem egyetemességéé, úgy, ahogyan a szabadság is az.

Aranka életében fontos szerepet játszott a személy és szabadság fogalma. A szent személyiség fogalma bekerült az Emberi Jogok Dekrétumába (1789), majd az 1791-es francia alkotmányba, hogy megihlesse az amerikai alkotmányt, $s$ alapjául szolgáljon minden demokratikus alkotmánynak. S akkor amikor Magyarországon erröl mindenki hallgat, Aranka nemcsak ilyen burkolt formában szól róla, hanem egyik kéziratában nyiltan beszél e fölötti öröméröl. Felteszem a kérdést, hogy vajon az öt elítélök tudtak erröl, s ha igen, volt-e merszük továbbra is oly nyílt anatémával kiüzni Arankát a fillozófia tartományából. Szerinte szabadon ítél, következtet, vagyis szabad az, aki rendelkezik a cselekvés képességével, bármi is legyen akaratának a meghatározója. A szabadon való cselekvés lehetősége alkalmat ad az embernek arra, hogy alkosson. Ez nem csupán az ember tökéletességre való vágyából ered - mely tökéletességet a Teremtő nagy alkotása, az univerzum testesíti meg -, hanem egy belső, hajtó ösztönből, mely a világot nemcsak megismerni akarja, hanem alkotásai által lemásolni és utánozni. A személyiség tulajdona az Ingenium is, ez vezérli az emberi cselekedeteket. Mivel Aranka úgy gondolja, hogy az elmében történő változások némelyikét maga az elme hozza létre, mások pedig az általunk használt érzékszervek útján keletkeznek az elmében, ezért a dolgoknak az emberi test szervein, vagyis az érzékeken keresztül megszerzett ismeretet nevezi érzékelésnek. A dolgoknak az ismeretét pedig, amelyet az elme közvetlenül teremt meg s mint jelenlevőt vizsgál, ideáknak nevezi. Az Ideákat nem csupán platóni értelemben használja, hanem itt is Kant nézeteire támaszkodik. Szerinte ugyanis lehetséges a tiszta észnek az erkölcsiség tapasztalata által megalapozott gyakorlati használata, amelynek során az ész túlemelkedik az érzékelhetőség határain, ezért az ember rendelkezhet elméletileg ugyan nem megalapozható, de a felelős cselekvéshez elegendő bizonyossággal az emberi szabadságot, Isten létezését, valamint a lélek halhatatlanságát illetően, fỏltéve, hogy e belátásokkal szemben támasztott minden elméleti ellenvetés semmisnek bizonyul.

Arankának biztosan hosszú utat kellett megtennie, hogy attól az önmagától, aki valamikor pap akart lenni, eljusson egy olyan szintre, ahol az ember ismeretének felvázolásában alig néhány sorban említi az Istent. Pope hatása lehet, hogy egy igen távoli Istent képzel el, aki bölcsen egybeszerkesztette a világot, de az ember csak ennek láttán gondolkozik el, és jut Isten létének gondolatára. Ezekkel a gondolatokkal zárja értekezését az emberről, talán nem is megváltozott Isten-képének kell tulajdonítanunk szủkszavỉiságát, hanem annak a ténynek, hogy egy másik írásában ez a téma foglal el központi helyet.

Aranka számára az ember alapos ismerete minden más bölcselkedés kezdetének tekinthető. Valószínủleg hosszú munka és különféle forrásokból merített tudás erdménye ez a munkája. Nem derült ki sehonnan (talán leveleiből több dolgot megtudhatriảnk), hogy, ha így gondolta, miért nem publikálta filozófiai tárgyú munkáinak az élén ezt az elmélkedést. Természetesen nem e munka fáradságos mivolta alapján kell itélkeznünk Aranka írása fỏlött, hiszen nyilvánvaló, hogy nem egy minden szempontból tökéletesen kidolgozott, mind szépirodalmi, mind pedig filozófiai igényeket kielégítő munkával van itt dolgunk. Kortársai lenézték, az utókor megfeledkezett Aranka György írásairól. Mennyiségileg tekintélyes filozófiai hagyatéka azonban nem érdektelen, további kutatása meglepô eredményeket hozhat. 


\section{Melléklet}

\section{Az Ember esmérete}

\section{Az Ember csak mint Jelenés}

1. Jelenés

a. Az Ember Nem. Központya van. Ez az Emberiség

b. A' világi sok Nemek. Hig, folyo, repulö, ércz, testek Eleji.

c. Az ember a' Nemeknek közönséges tulajdonságaival bir

2. Jelenés

a. Az Ember Alkotvány

b. Az Égi Testekis Alkotványok

3. Jelenés

a. A' Plánta. Oktállat és Ember a' mondottakrol külömbözik.

b. A' Nem alkotványi forma Erök egybe vagynak benne kötve.

c. A' Himben a Nem; a' nyösténybenn az alkotványi lakik

d. Édes, keserü, az illat mitsoda Jelenés?

e. Mi a' Lélek? Esmérö és Érzö alkotványok

4. Jelenés

a. A'Nagy Alkotvány. Ez a' Plántában s okt.állatban tökélletesedik, az emberben fejtỏdik ki, tökélletesedik

b. Tökélletesség, Boldogság. Az emberben mindenik kettöböl áll.

c. Az emberi kulső forma természeti

II. Az ember Esméretének két sarka van. Az emberi négy fö alkotvány: Élö, Esmérő, Érző és Személlyes. Az Esmérőnek és Érzönek négy Alkotványai: Külső, Belső, Alsoközép és FelsőKözép

5. Jelenés. Az Élö fö alkotvány

a. Az Élö fö alkotvány. Az alkotványok egymással, 's a Test a Lélekkel hogy köttetnek öszve?

b. Mitsoda Jelenés az embernek testére nézve valo külömbség?

6. Jelenés

A' 4. fö alkotyányok külömbsége

7. Jelenés ${ }^{301}$

a. A' külső alkotvány. Az Esmérö és Érző négy all Alkotvány mit külömböznek? A' Látásban két pont: $a^{\prime}$ Látás határozattya; $s$ abban az adattatott Jelenés és Látás. Tudás Elyonás, Eszrevétel, Képzelés, Emlékezet

${ }^{300}$ A kézirat közlésében megőriztem Aranka helyesirását, csak a I betüt változtattam s-re, a $\mathrm{B}$ betủt szre, valamint azokat a toldalékokat, amelyekre ő egyetlen betüt hasznảl teljesen kiírtam (megj. tỏlem, B.A.)

${ }^{301}$ A 7. Jelenés a kéziratból kimaradt. csak később szủrta be a szerző. 
(Esméret) ${ }^{302}$ Ezek által leszsz az Esméret

b. A Belső Alkotvány

(a. A 4 alkotványok közt valo külömbség.

Érzékenyedés, Érzés, Esméret

8. Jelenés) Erző vagy Esmérő

Az érző érzi a' Boldogságot és a Tökélletességet

A' Esmérőben 2 Tudás. Magatudása; az adattatott Minémüségeknek tudása az Emberiségre nézve ${ }^{303}$

Es az ltélö, a' Lelki esméret

c. Az alsoközép alkotványban. Ez is Esmérő és Érző.

Az Esmérő Tehetségek: Képzelö, Képzelödő és Itélő vagy Maga meghatározo

Az Érzőké: az ösztön, kívánság, Indulat, ... Köz Tehetségek: az önkéntség 's akarat

Munkájok az Esmérô Tehetségek részérōl ${ }^{30 t}$ : Érzékenyedés, Érzés, Ösztön és Szulkség, Kívánság a' Magad meghatározására vagy Meg nyugovás

Az Érző Tehetségek részéről az Akarat Czél

Önkéntség, Indulat, felháborodás

d. A Közép felső alkotvány Tehetségei: Ezekis Esmérők vagy Érzők. Az Esmérök: Okosság, Ertelem, Itélet, Okoskodás. Mit külömböznek?

e. A Közép Felső Erző alkotvány. Az Elme

9. Jelenés a. A'Személyes 4dik fö alkotvány

fö Tehettségei: Az Érzô felire nézve az Akarat és Szabadság

A Gondolo Tehettségére nézve: az Esz és Meggondolás

10. Jelenés a. Lélek, Belsỏ En

b. A' Személlyek közt való külömbség. A külső Én

b. Boldogságnak, Tökéletességnek érzése, Isten

Gondviselés, Kegyesség

Bévezetés helyett

(a'Munkának) annak rövid veleje

1. Az ember esméretének vonásait benneis találod az emberbenn, rajta kívülis. Ezek a' fővebb (apróbb) vonások közérülis, távulrolis adattatnak az embernek: de a természet rendinn csak ugy esmérhetni őket mint Jelenéseket.

1. Jelenés

a. Leg elsöbbenn adatik az ember mint Nem; minden ember ez alá tartozik. Az ember(t) esméret(benn) látásának határozattyábann (ez) a' leg szélesebb ki nézés (a Látás határozattyábann) ez. Hogy az ember Nem, ez azt teszi: hogy az emberi Nemben egy Középpont, egy nagy ember mellyhez a' több aprobb emberek, mint a' Naphoz a' körüle járo több aprobb csillagok vonattatnának, nincsen. Az a' pont, az emberiség, mellyhez minden ember vonattatik, (az) mindenikben vagyon; nem mint kőzép, hanem

\footnotetext{
${ }^{302}$ A zárójelben közölt szavak a kéziratból ki vannak húzva.

${ }^{303}$ A kéziratban itt vége az elsỏ oldalnak. A továbbiakban vízszintes vonallal jelölöm az oldalak végét.

${ }^{304} \mathrm{~A}$ dölt betüvel írott részt a kéziratba késöbb írta be szerzö.
} 
mint köz pont. Minden emberben vagyon: de nem felosztva; hanem mindenikben egész, és ugyan az.

b. Az emberbenn kívül, teli találom Nemmel az egész Tellyest. Hig, folyo, repülö, ércz, a' testeknek vékony Eleji; mind csupa és tulajdon Nemek. Közép pontyok nincsen csak köz pontyok: minden szem bennek maga Nemének egészsz tulajdonságaival bír; és maga Neme más részeihez vonszodik.

c. Az ember nem csupa Nem mint azok: de a' mennyiben Nem, a' Nemek közönséges tulajdonságaival bir; vonszodik egyik a' másikhoz; egymást szereti. Es ennyiben fel találom a nagy Természetet az emberbenn, 's megforditom az embert a' tellyes világbann.

\section{Jelenés}

a. De a' mellett a' Nemnek közönséges egysége mellett egy más forma Jelenés adja magát az emberbenn elé. Elsöbenn hogy az ember ollyan részekböl és tehettségekböl áll, mellyek egymástol külömböznek: de egy közép pontbann egybeköttettnek. Szemed bé hunyván p.o. a' hol viszket, ott vakarod. Hogy az élö emberek mint személlyek mind külömbözök de atyai, Házi s más természeti társaságokba mind bizonyos egységbe és közép pontba öszve vagynak kötve; s ennél fogva egyik a' másiknak sorsát érzi. Harmadszor; nem csak; hanem az elötte valokkal és következendökkel is, és azoknak nagy vagy alacsony tetteket érzi; mind azon egyalkotványbeli rész, melly egy egységbe vagyon a' Származás által szerkesztve mint közép pontba és egy nagy alkotványba. És igy az ember alkotvány.

b. Ezt látod az égi részeknek alkotványaikbannis: minden alkotványi részek különböznek; de egy közép pontyok vagyon, s abban egységek; függenek öszveis és egymástolis. Es igy ezenn tekintetbennis fel találod mind a' természetet az emberbenn: mind a' nagy természet(et)benn az embert.

\section{Jelenés}

a. De a' mi földünk szinénn, az emberbenn, Oktállatban és Plántában egy a' mondottaktol külömbözö Jelenés adja magát elé. Mindenik egy kicsiny csírábol lassan lassan fejtödik ki, él, és élni meg szünik: de maga utánn, maga Nemének más képviselöjét állittya bé maga hellyett. Ez a' Jelenés a' Him és Nyőstẻny erők, 's azoknak edénnyei és tehettségei által esik. A' Him és Nyöstényis szeretik egymást; de nem azért mint a' Nembenn hogy egy Nemüek: hanem azért hogy külömbözỏk; egyik nem ollyan mint a' másik. Micsoda Jelenés ez?

b. Ásd, vésd a' Természetet; ezt a Jelenést másunnan meg nem fejtheted: hanem csak a' mondott alkotványi és Nemforma külömbözö eröknek egyegységbe mint közép pontba valo köttetésekböl. A' Himbe a' Nem forma erő és a' (Nembe) nyỏsténybe az alkotványi van téve. Ez a' két erő a' Nagy alkotványbann annak fenn tartására el van választva; a' személlyekhenn pedig kủlönn különn egy alkotványi pontba öszve vagynak kötve: de ugy, hogy ki fejtödésekbe két költsönössön dolgozo alkotványokká válik.

c. Ez a'Nem forma erő a' plántában az édes, keserü, az illat sat. alkotványi forma a' Him és nyőstény edények, mozgás, kifejtődés, sat.

d. Az okt.állatbann s emberbenn a' Nem és alkotványi egybe köttetett erö egyközép pontbann, a' Lélek; mikor ez ki fejtődik az érző és esmérő két alkotvány leszsz belőle: a Himböl az esmérö, a másikbol az érző. 
a. Plánta, okt. állat, ember, (egy) mindeniket maga Nemébe vévén, kezdettől fogva végig nyomrol nyomra Képviselöibe változik ugyan: de Neme s alkotványi formájára nézve ugyan az marad. A' soknak egy alkotványi egysége vagyon: egy nagy alkotvánnya. Erre nézve a' nagy alkotványra nézve egy Jelenés adja elé magát, mellyből sokaprobb Jelenéseket meg érthetsz, és nevezetesenn az emberközött, és a' Plánta s okt.állat között valo külömbséget. Hogy a' Plántábann és Okt.állatbann maga egében és fơldébenn mind a' Nem, mind az alkotványi forma erő egy Jelenésben mint ugyszollván személlyben ki fejtődhetik, és az maga tökélletességét el érheti; ellenbenn a' nagy alkotvánnya egyikbe se tökélletes akik a' ki fejtődéssel; kezdettől fogva végig ugyan az marad: A' pok p.o. nem köti soha szebben háloját mint kezdetben: az emberbenn mint személlyben pedig, természet uttyán (pedig) se a' Nem se az alkotványi forma erő soha ki nemfejtődik egészszenn, tökélletességetelnem éri; ellenben a' Nagy alkotvány nyomrol nyomra fejtödik, s az tökélletesedik, és csak végre éri el a' tökélletességet.

b. (Ebböl foly) $E z$ az a' Jelenés, (hogy) amellyból az ember a' Boldogságnak és tökélletességnek érzését, 's arra valo vágyást veszi. A' Boldogság az a' Nem erők a' tökélletességet az alkotványinak ki fejtődése szerzi. A' Boldogság kettőből áll: az emberi szeretetnek, és magad Lelkinek, sérelem nélkül és ártatlanságbann valo tartásában és megbecsülésében mellybenn áll a' Morál. A'Tökélletességis kettőben áll: elsőben az egészsz emberi Nemzeteknek kifejtődésének $s$ annak társaságbeli tökélletesedésének; másodszor a magad személlyes ajándékaid ki fejtődésének emelésébenn, s annak érzésébenn; (Ennek a' tökélletesség) mellyeknek érzése a' Szépnek, nagynak és virtusnak az emberbe sarkantyuja.

c. Vallyon nem Veszedé ezekből észre az emberi külső formának a' természettel, az ő velevalo egybefüggéséhez képest valo (egységet) egybeszerkeztetyit. Két lábonn áll: egyik közülök az alkotványnak a' (fỏldnek) száraznak; más a' Nemnek, a' higoknak és folyotengerének van vetve. A' két erő egyesül: és adván a Him és nyőstẻny Nemek külömbsége, s edénnyei. Azutánn a derék alkotvánnak minden rẻszei, Sziv, lẻpp, májj, tüdő, belek sat. mind külömböznek; de egy elválhalhatatlan egységbe egybeköttettek. Azután felyül az az egység esmét két felé válik; ott van a' jobb és balkéz mint eszközök, egyik a' boldogságot más a' tökélletességet öleli; közböl a' Fö; az emberiség alkotványának teteje; $s$ annak kifejtődésének vége.

2. Ezek szerént az ember esméretének mintegy két sarka vagyon. Egyik a' Nagytermészetbenn, mellyenn az emberiség áll: másik az Emberiség végébenn, a' boldogságban és tökélletességbenn. Az eddig elé számlált Jelenések erre a' két sarokra nézve adják elé magokat: (az) de vagynak másokis mellyek tulajdon emberiek; és külömböző alkotványi Jelenésekbenn adják magokat az emberbenn elé. Illyenek elsöbenn. az emberi Élö, Esmérő, Érző, és Személlyes alkotványok. Másodszor az esmérỏ és érző alkotványoknak más négy alkotvảnyai: uma. Külső, Belső, Középalso és Közép felsỏ alkotványok. Ezek mind régi ujj Jelenések.

\section{Jelenés}

a. Az Élő alkotvány az emberbenn a' Test; egy tulajdonképpen magábann és éltető részeinek Eleire nézve nem emberi dolog; az Erzỏ és Esmérő alkotványok, mellyek tulajdon emberiek, az Nem s alkotványi középforma erőböl fejtödnek ki; a személlyes külsỏ alkotvány, mellybenn a mondott három egybe köttetik és a' belsỏ emberiségnek kủlső képviselője: egy ember mint Jelenés ezekből áll. De hogy kőttetnek ezek egybe nevezetessenn a' Test a' Lélekkel; s a' világi külső, és az emberi belső erők hogy 
dolgoznak költsönössön egymásba? Rövidenn. Egyik fö tehetsége a' Léleknek a' Nemforma erő, az esmérő tehettség; ez csak tehettség, ez magábann a' világonn semmivel nem jöhet kőzősülésbe; még maga a Lélek csak magára, más Lélekkel se jőhet költsönös munkába: hogy abba jöjjen egy harmadik; köztök köz dolognak kell közibe jơnni. Ez a' harmadik vagy köz dolog, a' másik fö tehettsége a Léleknek, az érzö tehettség. Ennek két tehettsége vagyon: a' tiszta tehettség, és az magának alkotványi edényeket formáló, $\mathrm{s}$ azokhoz képest dolgozó tehettség. Az első által az Esméret tehettséggel vagyon egybekötve; mint tehettség tehettséggel: a' másik által a' hozzá $\mathrm{s}$ az ő alkotványához és külömbözö edényeihez illő testi vékonyoknak mag Eleivel. Ezek közösülésbe vannak a' külsö higokkal 's azokáltal az egészsz tellyessel. Es igy a' külsö dolgok dolgoznak az emberi Élet alkotványában; ez az érző testi edényeknek változása által, az érző tehettségekbe, csak az esmérö alkotvány tehettségeibe: és megforditva. Természeti alkotványi Jelenés ugy a' Személlyes alkotvány is: mert ez, a' három belsö alkotványnak egyegységbe való egybe köttetése; 's a' mi azokban emberi; annak külső képviselöje.

b. De ezek szerént mitsoda Jelenés (az) : az Elet alkotványára nézve hogy minden Nem és alkotványi forma erő mindenben egy és ugyan az: mégis az ember, érző és esmérő tehettségekre nézve ollyan külömböző! Az élet alkotványának eleji az emberben, az alkotvány formáltatásakor nem egyenlök; külömbkülönféle mértékü elegyedéssel alkottyák az emberi testet: innen az érzö alkotvány

külömbözö ki fejtödése az ő edényeiben, tehettségeiben: s következés képpen az esmérö tehettségekbenn is. Innen a külsö belsö csonkaság, butaság, elmésség, egynek egyre másnak másra valo hajlandosága.

\section{Jelenés}

a. Emlitetett fellyebb, hogy az Esmérö és érző alkotvány négy all alkotványból áll; melly 'a' Külső, Belső, Közép also és Közép felső: mitsoda Jelenés ez? Egy példát adok: Felső a Nap, világosság van, Látsz; ez a' Látás a' Külsö alkotvány munkája. De a napba találsz nézni, a' szemed töle fáj, megbutulsz: ez a Közép also alkotvány dolga. Vagy eszedbe jut a' napnak felkelése, járása és elenyészése; 's abbol az emberi életnek mivolta, Boldogság, Isten sat.: ez a' Belső alkotvány munkája. Vagy egyikse ezek kôzül, mellyek kőzül az első a' Nap minemủségét, a' másik az érzö külső belső érzékenységeknek változását, a' harmadik a' Léleknek belső érzéseit illetik: hanem azokonn kivül gondolatba merülsz, hogy mi a' Világosság? az égi testek rendibenn $s$ a' Tellyesnek nagy alkotványában, mitsoda Jelenés a' Nap? Sat. Ez a' Közép felsö alkotvány dolga, mellynek tárgya a' tiszta gondolat.

b. Ekkor már Jelenés adja magát elé: hogy a' mit éreszsz, azt eszre veszed, és a' mit eszre vészsz, azt érzed; e' mitsoda Jelenés? Mikor az egészsz emberiségnek a' Személlyben alkotványi közép pontya $a^{\prime}$ Lélek, és ebben eleinten, mint csirában az esmérö Nemforma és az érző alkotványi forma erök egyegységbe egybe vagynak kötve akkor; természetszerẻnt az azokból ki fejtödnek két alkotványnak $\mathrm{s}$ azok tehettségeiknek az ö eredeti egybefuggéseket megkelltartani. Költsönös minden munkájok. De a' mondott alkotványokat külön külön vévén fel.

\section{Jelenés}

a. A' külső alkotványra nézve mitsoda Jelenés a' Külsö alkotvány és Esméret? Az esméret vagy érzés vagy az esmérés által esik. Az érző edény érzékenykedik, ezt észre veszed: 
ez az Érzés. Az esmérésre nézve, az esmérő edénynek, p.o. a szemnek adatik egy Élöfa. Ezzel két pont adattatik: egyik a' nagy Látás egészsz határozattya, erdő, mező, hegy sat. Másik az egy, az Élőfa benne. Veszem az utolsut, a' fát például; abban vagyon a' mi Néked nemadattatik: ez a' dolog magában: nincsen külső esmérete. Vagyon a' mi adatik: és ez a' mennyiben a' fára vitetik; a' Jelenés, a' mennyiben Réád a Látás. A' mennyiben a' mi adattatott benned alkotványi változást csinált: a' Tudás. De az Esmérés Elvonás által részenként esik, azis megannyi Tudás: de mint részTudás a' mennyiben azok a vonások a' Jelenés minemúségét, nem az alkotványt illetik: ez Eszre vétel. Ha az adattottat, elfordulván tỏle nemlátvais lảtod: ez a Képzelés. A' Képzelésnek az a' tulajdonsága: hogyha kettö(t) több(et) nékie együtt adattatott; azutảnn közülök egyik adattatván; a' másikat elé állittya melléje: ez az emlékezet: és ezis Tudás; de külső tudás. Mikor az esmérés, az észrevétel, képzelés és tudảs által az adott fának Mássát egészszen, vagy annyibann a' mennyiben elé tudja álitani: ekkor megvan az Esméret.

b. A' Belső alkotványra nézve: mitsoda Jelenés ez? Ez a' Lélek tulajdon alkotvánnya. Érző vagy Esmérő. Az érző az emberiségnek mint alkotvánnak két ágát érzi: a' Boldogságot és Tökélletességet. Mindeniket vagy közönségesenn az emberi Nemzetre, társaságra, s a' nagy alkotványra, és annak ki fejtődésére, s erkölcsbenn, emberi szeretetben, nevelésbenn, mesterségekbenn, tudományokbann való gyarapodására nézve: vagy pedig magára és a' maga tehettségére 's személlyes ajándékaira; kivált képpen pedig Lelkére nézve, ugy azzal mint vagyon (békességben, melly a' Lelki esméret)

békességbenn. Az Esmérő Belső Alkotványbann három Tudás és esmérő tehettség vagyon: első mikor Magadrol és Magad esméretével vagy, melly alkotványi; második, mikor a' belső érző alkotványbann adatott fenn emlitett változásokat, és azoknak minemúségeket az emberiségre nézve tudod és észre veszed; harmadik mikor a' Te magad szabad cselekedeteinek ahoz képest, a' mint azok az ỏ minemủségekre nézve a' magad érzésével, tudásával, s esméretével egyeznek, vagy nem egyeznek? Melly a' Lelki esméret.

c. Az also Közép alkotványra nézve, melly az okt.állatbanis köz. Mitsoda Jelenés ez? Ezis Esmérő vagy Érző. Az Esmérőnek csak három tehettsége: a' Képzelö, Képzelödő és Itélö vagy Maga meg határozo, melly ugyancsak a' Képzelés munkája. Az Érzőnek tehettségei: az Ösztön, Kivánság, Indulat, és ki munkálodás. Ezeknek köz eszköz tehettségei: az Önkéntség és Akarat. Ennek az alkotványnak munkálodásának rendi ez: a' külső vagy belső érző, vagy pedig az esmérő edények által adattatik a' képzelésnek, vagy megforditva ez által azoknak valami változás: ez az érzỏ edényekbenn az Érzékenyedés. Ezt észre veszed: ez Érzés. Ha az érzés az érző edényeket érdekli, és annak megszüntetésére valami Eszkőz kivántatik: ez az alkotványra nézve Ösztön, reád nézve Szükség. Ezek benned alkotványi- nyughatatlanságot szereznek a' Szükség kielégitésére: ez a' Kivánság. Mindezeket egyszersmind észre vévén a' Képzelés vagy eléállithattya $s$ azon meg nyugszik; ez a' Maga meghatározás. Az esméret alkotványábann mintegy Itélő Tảblản eképpen vẻgzödvén a' dolog: erre viszontag kőltsönbe érzékenyedik az Érző alkotvány, és a' kivánság, szükség, ösztön, mintegy also, végre hajto Tábla, igyekeznek azt a' Mit mint Czélt végre hajtani. Ebben az egész munkábann pedig az a' középpont, az a' köz tehettség melly a' Határozást a' kivánságra mint czélt által viszi: az Akarat. És ha mind ez a' munka a' felsỏ és Also Táblán ugyfollyt, hogy külsö eröltetésböl vagy történetböl nem esett semmi; hanem az ember vagy állat a' mondott tehettségeivel mint maga tulajdonáival élhetett: ez az Ônkéntség. Ha pedig ugy esik, hogy a' Képzelés a' szükséget ki elégités modját felnem talállya, 
vagy a' szükség igen szorgos, hirtelen valo kielégitést kiván, mellyre a' Képzelés nem elégséges, vagy igen nagy érzékenyedessel esvén az érző edényeket és más kemény és hig eszköz testi edényeketis érzékenyedésbehoz; ekkor a' Képzelést segitvén a' Képzelődés s ez által az érzékenyedés nevekedvén, se a' Meghatározásnak, se az akaratnak helye nincsen: ekkor és igy születnek az erőss Indulatok, felháborodások.

d. Mitsoda Jelenés a' Közép felső alkotvány. Ezis esmérő és Érző. Külömbözik a' többitől mind Materiájára, mind tehettségeire nézve. Materiája egy tiszta gondolat, melly elsőbenn szobann adattatik mint Jelben; másodszor az adatott gondolatnak nem egy külső Jelenés felel meg, hanem egy belső, mellynek a' gondolat Mássa; harmadszor nem azt esméri hogy az az adatott Jelenés, mellynek Mássa millyen hanem hogy az Mi? és negyedszer hogy az Igazé vagy nem? Esmérỏ tehettségei: az Okosság, Értelem, Itélet és Okoskodás. Az Okosság, melly csak az embernek tulajdona, munkás és láto, a' gondolatokat láttya, meg külömbözteti, egybefúggéseket által Láttya, és azokat illendő képpen egységbe rendeli. Az értelem esmérő és ki fejtő, az adatott gondolatot

ki fejti és meg esméri hogy Mi? Az Itélő az Okosságnak eszköz tehettsége, a' gondolatokat, kivált a' beszédbenn és munkábann valo egybefủggéseket láttya által. Az Okoskodás a' nagyobb Itélő tehettség; az Okosságnak és Értelemnek lajtorjája egy Harmadik Tertium által száll és hág fel az Igazságra; melly mind az Itéletnek mind az Okoskodásnak tulajdon tárgya.

e. Mitsoda Jelenés a' Felső Közép érző alkotvány? Ez azt teszi, hogy mitsoda Jelenés az Emberbenn az közönségessen hogyha a' külső világ az embernek külső Jelenéseket álitt eleibe; Költsönbe az emberis a' Világnak az ő munkáibann, mesterségekbenn s Tudományokbann másokat ad viszsza mint egységeket $\mathrm{s}$ alkotványi dolgokat. Különösönn, hogy a' Mesterségekbenn, Tudományokbann, és legalábbis a' Természetbenn a' Szépet, Nagyot, Tökélletest érzi és csudállya s utánna csinállya. Mitsoda Ér benne az az Érzö Ér, és mitsoda tehettség az a' tehettség, mellyben az az hajto ösztön vagyon és a' melly által az dolgozik, épitt, csinál, szerez? Hogy a' melly széles a' Világ, olly véghetetlen az ő kivánsága azt, $\mathrm{s}$ a' mi azon kivül vagyonis esmérni, tudni, megfogni, azoknak egységit által látni, s a' végre tanulni, tanitani, egymást $\mathrm{s}$ a' természetetis üzni? Az Okt.állat $\mathrm{s}$ az egészsz Tellyes meg fosztatott minden illyen érzéstől, ösztöntől és tehettségtől mint az Okosságok: ez csak csupán az Ember ajándéka. De mint a' Jég csap a' tủztől megnem gyul; ugy az emberbenn se volna ez az érzékenység, ha benne annak megfelelö bé vevő és ki dolgozo tehettség nem volna. Az Okosság vezérlése alatt ugyan: de tulajdonképpen, ez a' tehettség az Elme, Ingenium. Ez érzékenyedő és csinálo. Midőn a' belső külső, also és felső Közép alkotványok érző edénnyei és tehettségei érzékenyednek: ez azt észre veszi és érzi; abbol ösztönt veszen és az Okosság czéllyán az egységre, az Ėrtelem, Okoskodás, Képzelés és képzelődés által, mint társ, vagy eszköz tehettségek által dolgozik. Tárgya minden kivülröl vagy belölröl adatott szükség melly az embert vagy emberiséget érzékenyiti, a' külsőkre nézve mesterségeket talál s épitt: a' belsőkre nézve, millyenek a’ Jonak, Boldogsảgnak, Tökéletességnek, Világnak, Istennek belső adatott Szükségei, mellyeknek gondolattya Oskolai nyelven Ideának neveztetik; azoknak gondolattyait az Értelem ki fejtvén, azoknak gondolatbeli alkotványt ảd, és csinál, a' mit csinál, annak tiszta gondolattyát elébb ki rajzolván gondolatbann.

\section{Jelenés}

a. Mitsoda alkotvány Jelenés az Emberbenn a' Személly, annak tehettségei, és annak külömböző sorsa s tehettségeinek mértéke? A' Személly a' ki fejtödött belső 
emberiségnek, s annak az élő alkotvánnyal valo egybeköttetésének képviselője. Az egészsz emberi alkotványnak szüksegis, a' mennyiben azoknak ki elégitések csak az embertöl függ: a' Személly szükségei; és minden szabad munka az övé. Két fö tulajdon tehettsége vagyon: az Akarat és Szabadság. Az emberi Akarat az okt.állatétol annyit külömbözik: mint az ember az Oktalan állattal; az ember okossággal lévén felruháztatva; mellynek eszköz tehettségei a' Személlyben az Esz és Meggondolás. Ezek az ő Meghatározo Itélő tehettségeitis meg nemesitik: ez által akarattyai

tökéletesebb. Innen származik az emberi Szabadság, melly abban áll: a' mennyiben az ember nem csak ki dolgozo edényeivel, és külső s also tehettségeivel; hanem a' felsökkel is um. az Okossággal, értelemmel, s Okoskodással, s azonfellyül az észszel és meggondolással, mint maga tulajdonaival akadály nélkül él, s elhet, és élhetett mint magáéival.

b. Mitsoda Jelenés az továbbá: hogy egyik ember mint ember ollyan ember mint más; mégis a' Személly az ő emberi tehettségeire és sorsára nézve ollyan külömböző, a' milyennek láttyuk? Mind ezek alkotványi dolgok, és vagy az emberi nagyalkotványnak természetéböl um. közönséges társasági és házi nevelésből, ki fejtödésnek mértékéböl, születésből, munkassagbol vagy pedig az élő testi alkotvánnak kifejtödhetéséböl, épsegéböl és annak alkotásábol folyo külömböző hajlandoságoknak mivoltábol következnek. A' kettöt egybe vévén; minden alkotvánnak szükséges képpen külömböző részekböl kell állani: azẻrt az emberi nagy alkotvánnak minden részei csak emberböl állván; természeti dolog hogy azok a' személlyre nézve külömbözzenek. A' ki fejtődés is hasonloképpen természeti dolog: azért annak külömbségeiis természetszerént megválasztya a' Személyt a' Személytöl. Ezekböl foly a' Köz Jo, Maga Szeretete sat. A' Személy az, a' mi az emberben a' Külsö Ént teszi.

\section{Jelenés}

a. Az alkotványi Nem forma alkotványi középpont, mint emberi forma erö, magában mind egyforma: de a' Személlyesség az ötet másoktol megkülömböztetö vonások által annakis külömbséget ád; és ezek a' vonások a' Lélekbenn annakutánais minekutánna az élet alkotvánnya eloszlik, 's annak eloszlásával az esmérỏ és érző alkotványokis el romlottanak, megmaradnak eltörölhetetlenül: és ez a' meg maradás Személlyes dolog, belsö Én. Azok a' maradando vonások pedig azok fóképpenn mellyek tégedet az emberi Szeretetre 's az magad Lelked tisztaságára nézve, mint a' Nem erö tulajdonságaira nézve: azután az alkotványi ajándékokra vagy mind személlyes ajándékaidnak tökéletességére nézve másoktol meg külömböztetnek.

b. Ebben a' belső Enben adatik az embernek minden Nemzetnek nem csak Bodolgságnak, Tökéletességnek bizonyos érzése; hanem az Istennek, Gondviselésnek, és Kegyességnek érzése és gondolattyais; melyeknek gondolattyai, mint fellyebb Ideáknak neveztetnek: mitsoda Jelenségek ezek? Emberi természet a' belső alkotványba adatnak, az Elme érzékenyedik rájok, s az okosság igyekszik az Értelem ảltal ki fejteni őket. Leg rövidebb ki fejtése summásonn azoknak a' Jelenségeknek illyen forma: nincsen egy emberis hogy nevegye eszre, hogy az életben legkevesebb dolog a' mi a' világon tỏle, és azis szabad akarattyátol függ. Azombann az egészsz világ magában 's az ő sorsa és legszabadobb munkáiis nem ö általa, hanem egy fö, mind rajta, mind az egészsz Tellyessen kivül és fellyül valo erö által bölcsenn egybevagynak rendeltetve. Ez a' fö erô, és annak gondolattya szerzi az emberben az Istennek gondolattyát, azt ugy gondollya, mint teremtöjétis, Urátis, Attyátis, Baráttyátis, és annak rendelésénn megnyugoszik: ez az Istenben valo Bizodalom. Az a' maga elszánása, s annak 
gyakorlása hogy minden munkáinak és állapottyának közép pontyának, annak a' Fö Valoságnak tetszését tegye: az Isteni félelem.

Vallyon a' mondottakbol az emberbenn, hellyes egybefuggésbenn és alkotványi modon egy egybekötött egységbe vévén fel; adattatiké, adattathatiké az emberben mint emberben, valami ollyan változás vagy munka, mint Jelenés, mellyet lassan lassan idð̋vel azokbol ki nelehessen fejteni? Nékem ugy látszik: hogy az embernek esmérete, a' Bölcsességnek kezdete. 